\title{
Implementation of Character-Based Industrial Work Practices in SMK Arina Sidikalang
}

\author{
Din Oloan Sihotang \\ Universitas Negeri Medan \\ North Sumatra, Indonesia \\ oloansihotang81@gmail.com \\ Paningkat Siburian \\ Profesor at Universitas Negeri Medan \\ North Sumatra, Indonesia
}

\author{
Darwin \\ Lecturer at Universitas Negeri Medan \\ North Sumatra, Indonesia \\ Panigoran Siburian \\ Lecturer at Universitas Prima Indonesia \\ North Sumatra Indonesia
}

\begin{abstract}
This study aims to determine the process of management of industrial work practices at Arina Sidikalang Private Vocational School. This type of research is a descriptive study with a qualitative approach. Data collected using questions and observations. The study population was the Vice Principal in the field of Hubinmas, the Supervising Teacher of industrial work practices and XI grade students who carried out Industrial Work Practices in the academic year 2017/2018. The results showed that the management of industrial work practices at the SMK Arina Sidikalang carried out the functions of planning,implementation and evaluation in a simple form called the Character Work Industry Practices Model. 1) Planning of model is focused on the seven characters that were developed and then disseminated to students; religious, discipline, cooperation, hard work, responsibility, honest and polite. 2) The implementation of the Internship in the Arina Sidikalang Private Vocational School is in agreement with the Du / Di instructor to monitor and guide students systematically based on the program and schedule that has been determined, 3) Evaluation of Model is the process of evaluating student activities and practice results, including measuring student achievement in the fields of religious, disciplinary, hard work, cooperation, responsibility, honest, and polite.
\end{abstract}

Keywords- implementation; character; based, industrial, practices

\section{INTRODUCTION}

Field Work Practices which are now known as Industrial Work Practices which must be implemented in every Vocational School especially Vocational High Schools which are accustomed to being known as Vocational Schools must implement competency-based learning that is learning that is emphasized to equip competencies thoroughly to students. This competency covers aspects of attitude, knowledge and skills. Vocational education develops in accordance with the development of the demands of the industrial world, through two social institutions. First, social institutions in the form of work structures with organizations, division of roles or tasks, and behavior related to the selection, acquisition and utilization of careers. The second institution, in the form of education with its dual function, is as a medium of cultural preservation as well as a medium for social change. This policy requires both parties, namely schools and industry to jointly develop concepts, this is intended so that there is a match between schools and industries. Conformity in question is that the competencies that can be obtained by students in schools are the competencies obtained by students at school are the competencies needed in the industrial world. The industry must also play an active role in conveying technological progress to the school so that synchronization occurs between the industrial world and the world of education. The Government through the Ministry of Primary and Secondary Education has established a link and match policy that applies to all types and levels of vocational education in Indonesia.

To carry out vocational education which is held in 2 channels namely school education and non-school education, therefore in the preparation of the curriculum technical implementation is implemented in the form of industrial work practices (Prakerin). Internship is expected to be able to meet the needs of a professional workforce in their field and can create a professional workforce, where students who carry out internship are expected to apply the knowledge gained and at the same time learn it in the industry. Internship for vocational students is an integral part of the vocational curriculum. This program is very important for the success of students after graduation. The Internship Program provides opportunities for vocational students to adapt to the atmosphere or climate of the actual work environment both as independent workers, especially with regard to work discipline and provide input and feedback to improve and develop education. So that the implementation of Internship is not only centered on increasing student hard skills, Internship also needs to get an increase in student soft skills.

In the reality of learning in school, efforts to balance the three domains (apective, cognitive, psychomotor) are always sought, but in reality the dominant child is cognitive and psychomotor. As a result, students are rich in abilities that are hard skills but poor soft skills because the affective domain is 
neglected. This symptom appears in the output of education that has high intellectual ability, smart, class champion, but poor ability to build relationships, work together and tend to be selfish, even closed.

The results of an education is called quality in terms of products if it has one or more of the following characteristics: first, students show a high level of mastery of learning tasks that must be mastered in accordance with the goals and objectives of education - including are academic learning outcomes expressed in learning achievement (internal quality); second, the results of education in accordance with the needs of students in their lives so that by learning students not only "know" something, but "can do something" that is functional for his life (learning and earnings); third, educational outcomes are in accordance with or relevant to environmental demands, especially the world of work. From this point of view, relevance is one aspect or indicator of quality.

To overcome the above problems, management at the Vocational School is required not only to hold various programs in support of the learning process that direct students to be more developed in terms of affective and psychomotor, but also pay attention to the apective factors. One of the efforts undertaken by the school is to equip students and provide work experience directly to the industrial world in accordance with the student's expertise program concerned by referring to the Decree of the Minister of Education and Culture of the Republic of Indonesia number 323/U/1997 concerning the Implementation of Dual System of Education in vocational high schools [1].

Implementation of Internship is not free from problems and obstacles faced by industry in the field, some of the problems and constraints referred to are 1) discrepancies between the backgrounds of scientific disciplines of students with the business world for the purpose of working. 2). the process of adjustment by the early stage students 3 ). The quality of the meeting between the supervising teacher and the supervisor in the industrial world is not well yet, 4) the increase in the laziness of students after Prakerin.

Anticipating the problems and obstacles above, SMK Arina Sidikalang applies a model of industrial work practices developed by school management with the aim of suppressing the problems that arise arising in the implementation of the internship program called the character-based Internship model.

\section{LITERATURE REVIEW}

\section{A. Field Industrial practice}

The Industrial Work Practices Program or in Indonesian language is well known as "Prakerin" is basically an educational program formed from the Dual System Education (DSE) pattern which is operated in two places where the two places are given an assessment both by the teacher and the instructor who teaches practice at the partner institution. The writer [2] also mentioned that the Internship program covers vocational theory, basic practice and industrial work practices.
Purpose of Industrial Work Practices according to [2] for:

- Producing workers who have professional expertise, namely workers who have a level of knowledge, skills and work ethic that is in accordance with the demands of the workforce

- Enhance and strengthen the link and match between vocational training education institutions and the world of work.

- Improving the efficiency of the education and training process for qualified and professional workers.

- Give recognition and appreciation for work experience as a process of education.

B. Prakerin Character-Based Students

In the Complete Indonesian Dictionary, characters are interpreted as psychiatric qualities, character, character, character or character that distinguish one person from another. According to the Psychology Dictionary, character is a personality in terms of ethical or moral starting points, for example someone's honesty, and is usually related to relatively fixed traits. The author [3] writes literally, the meaningful character "mental or moral quality, moral strength, name and reduplication". While the writer [4] said that character education is a broad term that is used to describe the general curriculum and organizational features of schools that promote the development of fundamental values in children at school. This definition defines character education as a term that is commonly used to describe the curriculum and organization of schools that support the development of fundamental values in children in school.

\section{Student Character Former Values}

There are 18 (eighteen) character values sourced from religion, Pancasila, culture and national education goals to further strengthen the implementation of character education in educational units, namely: Religious, Honest, Tolerance, Discipline, Hard Work, Creative, Independent, Democratic, Taste Curious, Nationalism, Love for the Motherland, Appreciation for Achievement, Friendly/Communicative, Peaceful Love, Joy of Reading, Environmental Care, Social Care, Responsibility [1].

\section{Purpose of Character-Based Student Internship}

According to [4] states that the goal of character education is education inside and outside the school (in the business / industry) which should be placed in a dialectical dynamic framework, in the form of individual responses to the social and cultural surrounding, to be able to position himself to be perfect so that the potentials within him fully develop which makes him even more human.

Considering that there are 18 (eighteen) character values based on [5] that must be instilled in students in the learning process at school and there are 20 (twenty) character values based on the Minister of National Education Ministerial Regulation Number: 23 of 2006, in developing a program management model This character-based Internship only contains 7 (seven) characters. These seven character values are the dominant characteristics which must be developed in the 
spirit of the participants of the Internship which are also derived from the traditional [6], these characters are:

1) Religious; Obedient attitudes and behaviors in implementing religious teachings, being tolerant of the implementation of other religious worship, and living in harmony with followers of other religions.

2) Discipline: Actions that exhibit orderly and compliant behavior with various existing rules and regulations. Discipline is an action that shows orderly and obedient behavior in various provisions and regulations.

3) Hard Work: Behavior that shows earnest effort in overcoming various barriers to learning, tasks and completing tasks as well as possible.

4) Collaborate: Actions that show a sense of pleasure interacting, socializing, and cooperating with others. An important character that must be built so that students can achieve success, both at school, at the Internship and after graduation, is the ability to collaborate with friends or others.

5) Responsibility: The attitude and behavior of a person to carry out their duties and obligations, which he should do, towards oneself, society, environment (natural, social and cultural), country and God Almighty.

6) Honest: Behavior that is based on efforts to make himself as a person who can always be trusted in words, actions, and work. Honesty is the attitude and behavior of a person based on efforts to make themselves always be trusted in words and deeds.

7) Courtesy: Behavior that shows respect through attitudes, actions or behavior, good character, friendly in speaking greetings in accordance with manners; civilization; decency. Politeness is a subtle and good quality from the point of view of grammar and grammar to everyone.

\section{METHODOLOGY}

The study was conducted at the Private Vocational School Arina Sidikalang, Dairi Regency, North Sumatra Province. This study was conducted to determine the implementation of management of Industrial Work Practices in the Private Vocational School Arina Sidikalang by describing the research findings. The qualitative approach in this study aims to reveal existing data in the field by describing and interpreting things as they exist in the field and linking cause and effect to something that happened at the time of the research with the aim of obtaining a reality picture of the implementation of Character Based Industry Work Practice management. The object in this study is about the implementation of industrial work practices, namely planning, implementation and evaluation, while the subjects in this study are the managers of industrial work practices and students who do Internship.

This research is a field study research that intends to study intensively about the current background and interaction of a social, individual, group, institution, and community. In this case, the research used by researchers is more to research that is descriptive re-search. Data Analysis Data analysis in qualitative research was carried out before fieldwork, during the field, and after completion in the field.

\section{RESULTS AND DISCUSSION}

A. Results

The process of forming students' characters through Character-based Internship Management consists of 3 (three) major parts namely: a) Planning Phase, b) Implementation Phase, and c) Evaluation Phase. The three stages become a unity that has the aim to improve student character for the better through the implementation of Character-based Internship as shown in the fig 1.

\section{1) Planning Phase (Planning)}

During the Planning Stages, when carrying out the prebriefing of Prakrin, the seven characters that were developed were then socialized to students. Debriefing activities are carried out Arranging activities in a scheduled and organized and carried out aimed at fostering the character of students by touching the religious / spiritual side of students that affects the character development that is disciplined, cooperative, hard work, responsibility, honest, and polite. These activities are: Lectures, Spiritual Meditations, and Games

\section{2) Implementation Stage}

The School agrees with the Du / Di instructor to monitor and guide students systematically based on the program and schedule that has been determined (at least once a month by the Teacher, and every working day by industry and monitor the progress of the student's character at work by check the training participants' activity journals.

Guidance System The supervision and guidance of students in the field is intended so that the religious character, discipline, cooperation, hard work, responsibility, honesty and politeness develop well and student activities can be directed and take place well too. Because of this the guidance factor largely determines the overall success of the Prakerin program.

\section{3) Evaluation Stage}

Characteristic Internship Evaluation is a process of evaluating students' activities and practice results, including measuring the student's character achievements in the religious, disciplinary, hard work, cooperation, responsibility, honest, and polite manner. Then the measurement results are analyzed and the interpretation of the measurement results and giving a value to the level of mastery of the results of the practice achieved.

The activities of the evaluation carried out are:

- Distribute the assessment questionnaire to be filled by students. Through the questionnaire data is obtained to find out the extent of the development of student character. What characters are more prominent and must be improved again so that in the future policy can be taken.

- Collecting journal of Character-Based Internship activities to be examined and used as material in the granting of academic ideas.

- Students in groups or individually report CharacterBased Internship activities that have been followed in the form of simple reports and present them to other students. 


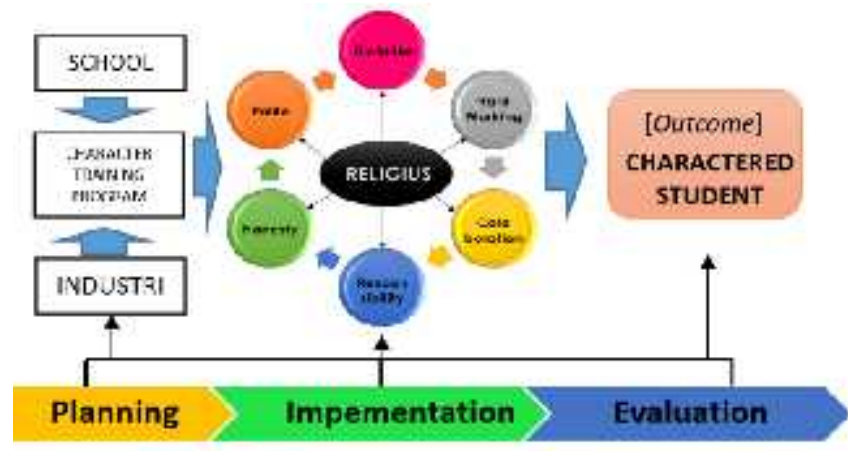

Fig 1. The process of implementing Internship

Before the model was tested, the initial stage was the stage of data collection using instruments/questionnaires distributed to 35 students as respondents who had implemented the old Prakerin model. The questionnaire was distributed with the aim of obtaining data on the extent to which the characters possessed by students and their understanding of the implementation of Internship. From the results of the distribution of questionnaires collected frequency distribution and from these calculations obtained the following results.

TABLE 1. RESULTS OF DATA COLLECTION ON OLD PRAKERIN MODELS IN ARINA SIDIKALANG PRIVATE VOCATIONAL SCHOOL

\begin{tabular}{|c|l|c|}
\hline No & $\begin{array}{c}\text { The observed } \\
\text { character }\end{array}$ & Average percentage \\
\hline 1. & Religious & $69,40 \%$ \\
\hline 2. & Discipline & $76,19 \%$ \\
\hline 3. & Hard work & $75,83 \%$ \\
\hline 4. & Cooperation & $73,06 \%$ \\
\hline 5. & Responsible & $62,65 \%$ \\
\hline 6. & Honest & $80,24 \%$ \\
\hline 7. & Polite & $79,90 \%$ \\
\hline & Average & $73,35 \%$ \\
\hline
\end{tabular}

Source: Reasearch Data

Furthermore, both the school supervisor and the industry mentor in the process of mentoring students fill the progress list of student characters on the form provided by the school. From the results of data processing can be reported in Table 2 .

TABLE. 2 LIST OF CHARACTER PROGRESS STUDENTS PARTICIPATING IN THE INTERNSHIP PROGRAM BASED ON THE BATAK CHARACTER OF PRIVATE VOCATIONAL SCHOOL ARINA SIDIKALANG

\begin{tabular}{|l|l|c|c|c|c|c|}
\hline \multirow{2}{*}{ No } & \multirow{2}{*}{$\begin{array}{c}\text { Character } \\
\text { developed }\end{array}$} & $\begin{array}{c}\text { Thin } \\
\text { king }\end{array}$ & Feeling & Acting & Attitude & $\begin{array}{c}\text { Respon } \\
\text { sible }\end{array}$ \\
\hline 1. & Religious & A & A & A & A & A \\
\hline 2. & Discipline & A & A & A & A & A \\
\hline 3. & Hard work & A & B & B & B & B \\
\hline 4. & Cooperation & A & A & A & A & A \\
\hline 5. & Responsible & A & A & A & B & B \\
\hline 6. & Honest & A & A & A & A & A \\
\hline 7. & Polite & A & A & A & A & A \\
\hline
\end{tabular}

Source: Processed data from Supervising Teacher's observation sheet Note: $\mathrm{n}=35$
From the results of data processing carried out, the data presentation of the two different samples can be seen in Table 3.

TABLE 3. DIFFERENCES IN THE LEVEL OF ACHIEVEMENT OF THE PERCENTAGE OF STUDENT CHARACTERS BETWEEN THE PRAKERIN MODEL BASED ON BATAK CHARACTERS AND THE OLD MODEL

\begin{tabular}{|l|l|c|c|}
\hline \multirow{2}{*}{ No. } & \multirow{2}{*}{$\begin{array}{c}\text { The Observed } \\
\text { Character }\end{array}$} & \multicolumn{2}{|c|}{ PRAKERIN MODEL } \\
\cline { 3 - 4 } & & NEW & OLD \\
\cline { 3 - 4 } & & $\%$ & $\%$ \\
\hline 1. & Religious & $90,71 \%$ & $69,40 \%$ \\
\hline 2. & Discipline & $93,81 \%$ & $76,19 \%$ \\
\hline 3. & Hard work & $90,71 \%$ & $75,83 \%$ \\
\hline 4. & Cooperation & $86,63 \%$ & $73,06 \%$ \\
\hline 5. & Responsible & $91,73 \%$ & $62,65 \%$ \\
\hline 6. & Honest & $97,62 \%$ & $80,24 \%$ \\
\hline 7. & Polite & $92,65 \%$ & $79,90 \%$ \\
\hline Rata-rata & $91,62 \%$ & $73,35 \%$ \\
\hline
\end{tabular}

Source: Process data for observation sheets

From the data in Table 3, shows that between the Character-Based Internship Model (the new model) and the Conventional Internship Model (the old model) has a significant difference. The average character of students using the old model was $73.35 \%$, while the character of students with the new model was $91.62 \%$. This implies that the use of a new model in Internship management can superiorly and convincingly improve character; religious, disciplined, hard work, cooperation, responsibility, honest and polite students become more positive. This also implies that the CharacterBased Industry Management Management model has been able to demonstrate its efficacy and effectiveness as a model of Industrial Work Management Management now and in the future.

\section{B. Discussion}

According to [7]author, there are several stages that should be passed in the preparation of an education program planning system, including:

- Need assessment phase, which is conducting a study of various needs or estimates needed in the development process or learning services in each education unit.

- $\quad$ Stage of formulation of goals and objectives, namely the formulation of goals and planning goals to be achieved.

- The policy and priority setting stage, which is to design what policy priorities will be implemented in the education service.

- The stage of the program and project formulation, namely the formulation of programs and projects implementing educational planning operational activities, involving educational services on academic and non-academic aspects.

- The feasibility testing stage, which is carried out due diligence tests on various resources (internal / external resources; or human / material resources). 
- Plan implementation phase, which is the stage of implementing educational planning to realize educational goals

- Phase evaluation and revision for future plans, namely activities to assess (evaluate) the success of the implementation of the program or education planning, as feedback (feedback or feedback), then the program revised the next education service plan for better.

The results showed that the three stages of the preparation of educational program planning consisted of: planning (preparation of Internship needs), implementation (Internship activities on site), and evaluation (planning assessment process). So that the relationship between statement author [8] and the results of this study is that the Planning, Implementation and Evaluation stages are the main activities that are important for implementing an educational program.

\section{CONCLUSIONS}

Planning in the Arina Sidikalang Private Vocational School focused on the seven characters that were developed and then disseminated to students. Debriefing activities are carried out Arranging activities in a scheduled and organized and carried out aimed at fostering the character of students by touching the religious / spiritual side of students that affects the character development that is disciplined, cooperative, hard work, responsibility, honest, and polite.

The implementation of the Internship in the Private Vocational School Arina Sidikalang is to agree with the indsutry instructor to monitor and guide students systematically based on the program and schedule that has been determined (at least once a month by the teacher, and every working day by industry and monitor the character's progress students at work by checking the training participants' activity journals.

The Internship Evaluation at Arina Sidikalang Private Vocational School is the process of evaluating the activities and results of student practice, including the measurement of student character achievements in the religious, disciplinary, hard work, teamwork, responsibility, honest, and polite manner. Then the measurement results are analyzed and the interpretation of the measurement results and giving a value to the level of mastery of the results of the practice achieved.

From the results of data processing, it shows that Arina's Private Vocational School uses the Character-based Internship Model.

\section{ACKNOWLEDGMENT}

For this chance I would like to express my special thanks to Dr. Darwin and Prof. Paningkat Siburian for sharing me their idea and sight guideing me this reseach. And to head master of SMK Swasta Arina Sidikalang, Mr Asi Sitanggang for supporting me finishing this study in his school lead.

\section{REFERENCES}

[1] DITPESMK, 2010. Inovasi Dalam Sistim Pendidikan. Potret Prkatik Tat Kelola Pendidikan Menengah Kejuruan. Direktorat Penelitian dan Pengembangan. Jakarta, 2010.

[2] Wahyu Nurharjadmo, 2008, Evaluasi Implementasi Kebijakan Pendidikan Sistem Ganda Di Sekolah Kejuruan, Jurnal Spirit Publik Volume 4, Nomor 2 Halaman: 215 - 228 ISSN. 1907 - 0489

[3] Afandi Anas. (2007). "Evaluasi Pelaksanaan Praktik Kerja Industri Siswa SMK Kompetensi Keahlian Teknik Bangunan Di Kota Makasar". Tesis. Yogyakarta: PascaSarjana UNY

[4] Akhmad Muhaimin Azzet.2011. Urgensi Pendidikan Karakter di Indonesia: Revitalisasi Pendidikan Karakter terhadap Keberhasilan Belajar dan Kemajuan Bangsa. Yogyakarta:Ar-Ruzz Media.

[5] O`Connor, L. E., Rangan, R. K., Berry, J. W., Stiver, D. J., Hanson, R., Ark, W., et al. (2015). Empathy, compasionate altruism and psychological well-being in contemplative practitioners across five traditions. Journal of Psychology, 6, 989-1000

[6] Kementerian Pendidikan dan Kebudayaan. 2012. Bahan Uji Publik Kurikulum 2013. Jakarta: Kementerian Pendidikan dan Kebudayaan.

[7] Banghart, FW. Dan Trull, Jr., 1973. Educational Planning, London; The Macmillian Company Brown, L. B. 1998

[8] Abna Hidayati,dkk. 2014. TheDevelopmentof Character EducationCurriculum for Elementary Student in WestSumatera. International Journal of EducationandResearch Vol.2 No. 6June2014.Hlm.189-198. 